\title{
PENERAPAN MODEL PEMBELAJARAN KOOPERATIF TEKNIK THINK PAIR SHARE UNTUK MENINGKATKAN MOTIVASI BELAJAR PADA MATA PELAJARAN DASAR-DASAR PERBANKAN SISWA KELAS X AKUNTANSI SMK MUHAMMADIYAH MAGELANG TAHUN AJARAN 2016/2017
}

\author{
THE APPLICATION OF THE THINK PAIR SHARE TECHNIQUE OF THE \\ COOPERATIVE LEARNING MODEL TO IMPROVE ACCOUNTING LEARNING \\ MOTIVATION IN THE SUBJECT OF PRINCIPLES OF BANKING FOR GRADE X \\ STUDENTS OF ACCOUNTING AT SMK MUHAMMADIYAH MAGELANG IN THE \\ ACADEMIC YEAR OF 2016/2017
}

Oleh:

Bagas Dwi Pratomo

Pendidikan Akuntansi Universitas Negeri Yogyakarta

bagasssnort@gmail.com

\section{Sukanti}

Staf Pengajar Jurusan Pendidikan Akuntansi Universitas Negeri Yogyakarta

\begin{abstract}
Abstrak
Penelitian ini bertujuan untuk mengetahui peningkatan Motivasi Belajar pada Mata Pelajaran Dasar-dasar Perbankan Siswa Kelas X Akuntansi SMK Muhammadiyah Magelang Tahun Ajaran 2016/2017 melalui penerapan model pembelajaran kooperatif Think Pair Share. Penelitian ini merupakan Penelitian Tindakan Kelas yang dilaksanakan melalui dua siklus dalam dua pertemuan, setiap siklus terdiri dari empat rencana tindakan, yaitu perencanaan, pelaksanaan tindakan, pengamatan, dan refleksi. Hasil penelitian menunjukkan bahwa Penerapan Model Pembelajaran Kooperatif Teknik Think Pair Share dapat meningkatkan Motivasi Belajar pada Mata Pelajaran Dasardasar Perbankan siswa kelas X Ak SMK Muhammadiyah Magelang Tahun Ajaran 2016/2017 yang dibuktikan dengan peningkatan persentase skor observasi sebesar $81.13 \%$. Kemudian berdasarkan data dari angket skor rata-rata sebesar77.88\%.
\end{abstract}

Kata kunci: Think Pair Share, Motivasi Belajar

\begin{abstract}
The aim of this research was to improve the students' learning motivation in the subject of principles of banking for grade X students of accounting at SMK Muhammadiyah Magelang in the academic year of 2016/2017 through the application of the think pair share technique. This study was categorized into classroom action research. There were two cycles applied in two meetings in which the steps of the research were planning, action, observation and reflection. The results showed that the application of the of the think pair share technique of the cooperative learning model was effective to improve accounting learning motivation of grade X students of accounting at SMK Muhammadiyah Magelang in the academic year of 2016/2017, indicated by the improvement of the percentage of the scores observation is $81.13 \%$. According to the questionnaires is $77.88 \%$.
\end{abstract}

Keywords: Think Pair Share, Learning Motivation

\section{PENDAHULUAN}

Pendidikan merupakan salah satu indikator keberhasilan suatu negara dalam mengelola sumber daya manusia di negaranya. Pendidikan akan dikatakan baik apabila proses yang terjadi dalam 
pendidikan itu dapat mengimbangi perkembangan zaman yang begitu cepat, oleh karena itu sangat penting bagi suatu negara dalam usahanya mengembangkan dan memajukan pendidikan untuk menjadi lebih baik, sesuai dengan tujuan nasional seperti yang tercantum dalam aliniea IV, Pembukaan UUD 1945. Selain peran motivasi belajar yang menjadi salah satu aspek penting dalam pencapaian proses pembelajaran yang optimal, juga terdapat aspek lain yang perlu dipertimbangkan yaitu bentuk pendekatan pembelajaran. Pendekatan pembelajaran yang diterapkan, dalam hal ini fokus terhadap guru sebagai pendidik, maka seorang guru memiliki peranan penting dalam penerapan model pembelajaran kaitannya dengan menumbuhkan motivasi belajar siswa melalui berbagai aktivitas belajar yang didasarkan pada pengalaman dan kemampuan guru kepada siswa secara individual.

Guru sebagai mediator di dalam sebuah proses pembelajaran dapat meningkatkan motivasi ekstrinsik dengan memberikan suatu pembelajaran yang tepat serta penciptaan suasana pembelajaran yang menyenangkan sehingga siswa dapat terlibat aktif dalam proses pembelajaran. Oleh sebab itu, perlu dikembangkan model pembelajaran yang menumbuhkan suasana yang menarik dan menyenangkan yang dapat meningkatkan motivasi. Tujuan pembelajaran adalah terwujudnya efisiensi dan efektivitas kegiatan belajar yang dilakukan peserta didik (Isjoni, 2013:14).

Salah satu teknik dalam model pembelajaran kooperatif adalah teknik Think Pair Share (Berpikir, Berpasangan, Berbagi), teknik ini memberikan kesempatan kepada siswa untuk dapat mengembangkan keterampilannya dalam berpikir, menjawab, dan berkomunikasi antara satu dengan lainnya serta bekerja saling membantu dalam kelompok kecil.

Model Pembelajaran Teknik Think Pair Share ini diawali dengan guru memberikan materi atau permasalahan yang kemudian masing-masing siswa diberikan kesempatan untuk berpikir (Think) sendirisendiri terlebih dahulu tentang jawaban atas materi atau permasalahan yanag telah disampaikan, kemudian siswa mendiskusikan dengan pasangan (Pair) mereka masing-masing untuk mengutarakan hasil pemikiran masing-masing, selanjutnya guru meminta untuk setiap pasangan menshare, menjelaskan dan menjabarkan hasil diskusi dengan kelompok lain, diakhiri dengan kesimpulan yang disampaikan oleh guru. Dengan model pembelajaran tersebut diharapkan dapat meningkatkan motivasi belajar peserta didik.

Berdasar observasi pendahuluan ketika peneliti melaksanakan PPL (Praktik Pengalaman Lapangan) pada 18 Juli sampai dengan 16 Agustus 2016 di kelas X Akuntansi SMK Muhammadiyah Magelang dapat diketahui bahwa Motivasi Belajar pada Mata Pelajaran Dasar-dasar Perbankan siswa masih rendah dan belum dioptimalkan, kurang tekun menghadapi tugas, kurangnya kegiatan yang menarik dalam belajar, kurangnya dorongan dan kebutuhan belajar, dan lingkungan belajar yang kurang kondusif.

Siswa yang merasa bosan, terlihat dari tingkah laku dan sikapnya selama proses pembelajaran, siswa cenderung lebih suka membicarakan hal di luar materi pembelajaran dengan temannya dari pada fokus terhadap materi di saat guru menjelaskan. Siswa juga menunjukkan respon yang kurang terhadap pembelajaran dan tidak segera mengerjakan tugas yang telah diberikan oleh guru serta motivasi belajar siswa untuk berpartisipasi di dalam kelas masih belum menunjukkan motivasi belajar yang tinggi. Oleh karena itu perlu diterapkannya suatu model pembelajaran yang dapat meningkatkan motivasi belajar siswa dalam mengikuti kegiatan belajar mengajar yang dirasa lebih bervariasi dan siswa menjadi lebih berpartisipasi dalam pembelajaran sehingga siswa tidak merasa bosan. Pembelajaran kooperatif tipe Think Pair Share cocok digunakan untuk 
mengatasi permasalahan tersebut, karena dengan metode pembelajaran tersebut siswa diharuskan untuk berfikir secara mandiri setelahnya berdiskusi dengan kelompoknya dan mengungkapkan hasil diskusi dengan kelompok lain di dalam kelas.

Berdasarkan latar belakang masalah yang telah diuraikan di atas, maka peneliti tertarik untuk melaksanakan penelitian tindakan kelas dengan judul "Penerapan Model Pembelajaran Kooperatif dengan Teknik Think Pair Share untuk Meningkatkan Motivasi Belajar pada Mata Pelajaran Dasar-dasar Perbankan Siswa Kelas X Akuntansi SMK Muhammadiyah Magelang Tahun Ajaran 2016/2017”.

\section{METODE PENELITIAN}

\section{Jenis Penelitian}

Berdasarkan permasalahan yang telah diuraikan sebelumnya, maka jenis penelitian ini digolongkan penelitian tindakan kelas atau CAR (Classroom Action Research). Menurut H.E. Mulyasa (2011: 13) PTK merupakan suatu upaya untuk mencermati kegiatan belajar sekelompok peserta didik dengan memberikan sebuah tindakan (treatment) yang sengaja dimunculkan. Tindakan tersebut dilakukan oleh guru, oleh guru bersama-sama dengan peserta didik, atau oleh peserta didik di bawah bimbingan dan arahan guru, dengan maksud untuk memperbaiki dan meningkatkan kualitas pembelajaran

Penelitian ini diterapkan melalui bentuk kolaboratif. Peneliti berkolaborasi dengan guru melaksanakan penelitian ini dilaksanakan sebanyak 2 siklus.

\section{Waktu dan Tempat Penelitian}

Penelitian ini telah dilaksanakan di kelas X Akuntansi SMK Muhammadiyah Magelang Tahun Ajaran 2016/2017. Penelitian telah dilaksanakan pada bulan April 2017. Adapun tahapan yang dilakukan yaitu, tahap persiapan, pelaksanaan, dan pelaporan.

\section{Subjek dan Objek Penelitian}

Subjek dalam penelitian ini adalah siswa kelas $X$ Akuntansi SMK Muhammadiyah Magelang yang berjumlah 22 siswa (1 laki-laki, 21 perempuan). Objek penelitian yaitu Motivasi Belajar pada Mata Pelajaran Dasar-dasar Perbankan siswa kelas X Akuntansi melalui penerapan Model Pembelajaran Kooperatif dengan Teknik Think Pair Share.

\section{Teknik Pengumpulan Data}

Teknik pengumpulan data pada penelitian ini menggunakan teknik observasi, angket, dan dokumentasi.

\section{Instrumen Penelitian}

Instrumen penelitian yang digunakan yaitu pedoman observasi dan angket. Pedoman observasi dan angket menggunakan ciri-ciri Motivasi Belajar menurut Sardiman A. M (2011: 83-84).

\section{Teknik Analisis Data}

Penelitian ini menggunakan teknik analisis data deskriptif dengan presentase. Menurut Sugiyono (2010: 137), data yang diperoleh dari hasil observasi dan angket merupakan data kuantitatif. Dilakukan analisis dari hasil tersebut untuk mengetahui skor motivasi belajar akuntansi siswa. Dari hasil persentase akan diketahui peningkatan yang terjadi terkait Motivasi Belajar siswa. Hasil analisis kemudian disajikan dalam bentuk uraian deskriptif.

\section{HASIL PENELITIAN DAN PEM- BAHASAN}

Penelitian ini bertujuan untuk mengetahui peningkatan Motivasi Belajar pada Mata Pelajaran Dasar-dasar Perbankan Siswa Kelas X Akuntasi SMK Muhammadiyah Magelang Tahun Ajaran 2016/2017 melalui model pembelaljaran kooperatif Think Pair Share yang dilaksanakan melalui dua siklus dalam dua pertemuan. Sebelum melakukan dua siklus, terlebih dahulu dilakukan observasi awal untuk mengetahui seberapa besar perbedaan 
motivasi siswa sebelum dan sesudah diterapkan model pembelajaraan kooperatif Think Pair Share.

\section{Observasi Awal}

Sebelum menerapkan model pembelajaran kooperatif teknik think pair share, peneliti melakukan observasi awal pembelajaran akuntansi pada mata pelajaran dasar-dasar perbankan. Dari observasi yang telah dilakukan pada hari Rabu, 19 April 2017 pada jam ke 1 dan ke 2 dengan menggunakan pedoman observasi yang telah disiapkan.

Dari data yang diperoleh, menunjukkan skor Motivasi Belajar pada Mata Pelajaran Dasar-dasar Perbankan siswa kelas X Ak SMK Muhammadiyah Magelang sebesar 53.98\%. Hal tersebut berarti bahwa Motivasi Belajar pada Mata Pelajaran Dasar-dasar Perbankan siswa belum mencapai kriteria minimum yang telah ditentukan yaitu sebesar $75 \%$. Hasil dari observasi awal ini dijadikan pedoman bagi peneliti untuk memilih kelompok pada siklus I.

\section{Hasil Penelitian Siklus I}

Siklus I dilaksanakan pada hari Selasa, 25 April 2017 pada jam ke 5 dan ke 6 . Materi pembelajaran yang diberikan pada siklus I adalah pengertian dan unsur-unsur kredit bank. Langkah-langkah yang dilaksanakan peneliti pada siklus I adalah sebagai berikut:

a. Perencanaan

Pada tahap perencanaan peneliti menyiapkan segala sesuatu yang akan digunakan pada saat pelaksanaan, seperti:

1) Menyusun Rencana Pelaksanaan Pembelajaran (RPP) dan materi pembelajaran kompetensi dasar menjelaskan pengertian, unsur-unsur, tujuan, fungsi dan jenis kredit bank yang telah disesuaikan dengan Model Pembelajaran Kooperatif Teknik Think Pair Share dan dikonsultasikan dengan guru mata pelajaran dasar-dasar perbankan.
2) Menyiapkan lembar observasi yang akan digunakan untuk mencatat kemunculan indikator Motivasi Belajar pada Mata Pelajaran Dasar-dasar Perbankan.

Menyiapkan angket yang akan dibagikan pada siswa kelas X Ak untuk mengetahui Motivasi Belajar pada Mata Pelajaran Dasar-dasar Perbankan.

Konsultasi pada guru mata pelajaran mengenai hal-hal yang berkaitan dengan pelaksanaan proses pembelajaran yang akan dilaksanakan.

b. Pelaksanaan Tindakan

Pelaksanaan tindakan pada siklus I adalah sebagai berikut:

1) Kegiatan Awal

a) Guru mengkondisikan kelas untuk berdo'a yang kemudian mendampingi siswa untuk melakukan kultum di depan kelas.

b) Guru menyampaikan tujuan pembelajaran yang hendak dicapai dan memberikan gambaran tentang materi pengertian dan unsur-unsur kredit bank.

c) Guru memberikan apersepsi dan menjelaskan tentang model pembelajaran yang akan digunakan yaitu Model Pembelajaran Kooperatif Teknik Think Pair Share.

2) Kegiatan Inti

a) Guru memperagakan materi yang akan diberikan pada peserta didik.

b) Siswa diberikan soal untuk memikirkan jawaban sementara secara individu (Think) selama 10 menit.

c) Siswa diminta untuk berdiskusi dengan pasangannya untuk mendiskusikan (Pair) soal yang sebelumnya telah diberikan selama 15 menit.

d) Siswa diminta untuk mempresentasikan (Share) hasil diskusi bersama pasangannya selama 30 menit.

3) Kegiatan Akhir

a) Guru bersama siswa mereview materi yang telah dipelajari.

b) Guru menyampaikan materi untuk pertemuan berikutnya dan mengakhiri pembelajaran. 
c) Peserta didik mengisi angket.

4) Pengamatan

Berdasarkan pengamatan yang telah dilakukan oleh peneliti dan observer pada kegiatan pembelajaran siklus I, diperoleh hasil Motivasi Belajar pada Mata Pelajaran Dasar-dasar Perbankan yang diukur melalui lembar observasi dengan penerapan Model Pembelajaran Kooperatif Teknik Think Pair Share di kelas X Ak SMK Muhammdiyah Magelang.

Dari data observasi tersebut dapat diketahui bahwa terdapat 7 indikator yang belum mencapai kriteria minimal yang ditentukan yaitu indikator ulet menghadapi kesulitan (61.4\%), menunjukkan minat terhadap bermacam-macam masalah (59.65\%), lebih senang bekerja mandiri (64.91\%), cepat bosan pada tugas-tugas yang rutin $(59.65 \%)$, dapat mempertahankan pendapatnya $(63.16 \%)$, tidak mudah melepaskan hal yang diyakini itu (52.63\%), dan senang mencari dan memecahkan masalah soal-soal $(70.18 \%)$. Data tersebut selanjutnya digunakan sebagai salah satu bahan refleksi dan pedoman untuk memilih pasangan pada siklus II.

Dari data angket ditunjukkan bahwa pada siklus I terdapat 7 indikator yang belum mencapai kriteria minimal yang ditentukan yaitu indikator ulet menghadapi kesulitan (72.81\%), menunjukkan minat terhadap bermacam-macam masalah $(72.81 \%)$, lebih senang bekerja mandiri (64.91\%), cepat bosan pada tugas-tugas yang rutin $(65.35 \%)$, dapat mempertahankan jawabannya (71.49\%), tidak mudah melepaskan hal yang diyakini itu $(60.96 \%)$, dan senang mencari dan memecahkan masalah soal-soal (57.89\%), sedangkan indikator tekun menghadapi tugas telah mencapai kriteria minimal dengan hasil $76.32 \%$.

Dari data yang diperoleh dengan teknik dan observasi dapat diketahui bahwa terdapat 7 indikator yang belum mencapai kriteria minimal dan 1 indikator yang telah mencapai kriteria minimal yaitu indikator tekun menghadapai tugas. Indikator tekun menghadapi tugas yang telah mencapai kriteria minimal mencerminkan bahwa peserta didik telah mengerjakan soal yang diberikan oleh guru.

5) Refleksi

Berdasar hasil data observasi dan data angket pada siklus I dapat diketahui bahwa 7 dari 8 indikator Motivasi Belajar pada Mata Pelajaran Dasar-dasar Perbankan masih belum optimal. Kekurangan yang terjadi pada siklus I tersebut adalah:

1) Peserta didik belum terbiasa dengan model pembelajaran kooperatif teknik Think Pair Share sehingga masih banyak peserta didik yang bingung sehingga belum bisa mengikuti alur pembelajaran.

2) Peserta didik kurang serius dalam proses diskusi, banyak peserta didik yang membicarakan hal di luar konteks pelajaran sehingga kelas menjadi gaduh.

3) Peserta didik tidak memanfaatkan tahap Pair secara maksimal karena peserta didik lebih memilih bertanya langsung kepada guru daripada berdiskusi dengan pasangannya.

Berdasarkan kekurangan pada siklus I tersebut, maka disusun rencana perbaikan untuk siklus II sebagai berikut:

1) Menekankan pada kerjasama yang terarah dengan memberikan penjelasan secara detail tentang prosedur model pembelajaran kooperatif teknik Think Pair Share.

2) Memberi teguran bagi peserta didik untuk tidak berdiskusi di luar konteks pelajaran agar tercipta kemauan untuk bekerja sama.

\section{Hasil Penelitian Siklus II}

Siklus II dilaksanakan pada hari Rabu, 26 April 2017 pada jam ke 1 dan ke 2. Materi pembelajaran yang diberikan pada siklus II adalah tujuan, fungsi, dan jenisjenis kredit bank. Langkah-langkah yang dilaksanakan peneliti pada siklus II adalah sebagai berikut:

\section{a Perencanaan}

Berdasarkan data yang diperoleh dari siklus I dapat di identifikasi bahwa skor 
Motivasi Belajar pada Mata Pelajaran Dasar-dasar Perbankan masih di bawah skor minimal yang ditentukan yaitu $75 \%$. Pada tahap siklus II ini dilakukan perbaikan pada hal-hal yang kurang dalam pelaksanaan siklus I sehingga pada siklus II ini pelaksanaan bisa lebih baik.

Pada tahap pelaksanaan siklus II peneliti menyiapkan segala sesuatu yang akan digunakan pada saat pelaksanaan, seperti:

1) Menyusun Rencana Pelaksanaan

Pembelajaran (RPP) dan materi

pembelajaran kompetensi dasar menjelaskan pengertian, unsur-unsur, tujuan, fungsi dan jenis kredit bank yang telah disesuaikan dengan Model Pembelajaran Kooperatif Teknik Think Pair Share dan dikonsultasikan dengan guru mata pelajaran dasar-dasar perbankan.

2) Menyiapkan lembar observasi yang akan digunakan untuk mencatat kemunculan indikator Motivasi Belajar pada Mata Pelajaran Dasar-dasar Perbankan.

3) Menyiapkan angket yang akan dibagikan pada siswa kelas X Ak untuk mengetahui Motivasi Belajar pada Mata Pelajaran Dasar-dasar Perbankan.

4) Konsultasi pada guru mata pelajaran mengenai hal-hal yang berkaitan dengan pelaksanaan proses pembelajaran yang akan dilaksanakan.

b Pelaksanaan Tindakan

Pelaksanaan tindakan pada siklus II adalah sebagai berikut:

1) Kegiatan Awal

a) Guru mengkondisikan kelas untuk berdo'a yang kemudian mendampingi siswa untuk melakukan kultum di depan kelas.

b) Guru menyampaikan tujuan pembelajaran yang hendak dicapai dan memberikan gambaran tentang materi tujuan, fungsi, dan jenis-jenis kredit bank.

c) Guru memberikan apersepsi dan menjelaskan tentang model pembelajaran yang akan digunakan yaitu Model Pembelajaran Kooperatif Teknik Think Pair Share.

2) Kegiatan Inti

a) Guru memperagakan materi yang akan diberikan pada peserta didik.

b) Siswa diberikan soal untuk memikirkan jawaban sementara secara individu (Think) selama 10 menit.

c) Siswa diminta untuk berdiskusi dengan pasangannya untuk mendiskusikan (Pair) soal yang sebelumnya telah diberikan selama 15 menit.

d) Siswa diminta untuk mempresentasikan (Share) hasil diskusi bersama pasangannya selama 30 menit.

3) Kegiatan Akhir

a) Guru bersama siswa mereview materi yang telah dipelajari.

b) Guru menyampaikan materi untuk pertemuan berikutnya dan mengakhiri pembelajaran.

c) Peserta didik mengisi angket.

c Pengamatan

Berdasarkan pengamatan yang telah dilakukan oleh peneliti dan observer pada kegiatan pembelajaran siklus I, diperoleh hasil Motivasi Belajar pada Mata Pelajaran Dasar-dasar Perbankan yang diukur melalui lembar observasi dengan penerapan Model Pembelajaran Kooperatif Teknik Think Pair Share di kelas X Akuntansi SMK Muhammdiyah Magelang.

Dari data observasi dapat diketahui bahwa skor dari tiap indikator telah mencapai lebih dari batas skor minimal, begitu juga dengan skor rata-rata yang telah mencapai $81.13 \%$. Skor tersebut menunjukkan bahwa Motivasi Belajar pada Mata Pelajaran Dasar-dasar Perbankan Siswa Kelas X Akuntansi SMK Muhammadiyah telah mengalami perbaikan dari siklus I dan memenuhi kriteria minimal yang ditentukan.

Dari data angket dapat diketahui bahwa skor dari tiap indikator telah melampaui kriteria minimal yang telah ditetapkan yaitu $75 \%$. Kemudian skor ratarata yang didapat pun sudah mencapai $77.88 \%$. 
Dari data yang diperoleh dengan teknik angket dan teknik observasi dapat diketahui bahwa seluruh indikator telah mencapai kriteria minimal yaitu $75 \%$. Walaupun indikator menunjukkan minat terhadap bermacam-macam masalah telah mencapai kriteria minimal dengan skor $76.47 \%$ pada teknik observasi dan $75.98 \%$ pada teknik angket, tetapi skor tersebut menunjukkan skor terendah dari indikator lainnya. Indikator tersebut mencerminkan bahwa peserta didik belum maksimal memperhatikan pada saat guru menyampaikan materi.

d Refleksi.

Berdasarkan data yang diperoleh dapat diketahui bahwa terjadi peningkatan dari indikator-indikator yang digunakan. Rencana perbaikan pada siklus I berhasil diterapkan pada siklus II yang dapat dibuktikan dengan tercapainya kriteria minimal yang ditetapkan pada tiap indikator yaitu tekun menghadapi tugas, ulet menghadapi kesulitan, menunjukkan minat terhadap bermacam-macam masalah, lebih senang bekerja mandiri, cepat bosan pada tugas-tugas yang rutin, dapat mempertahankan pendapatnya, tidak mudah melepaskan hal yang diyakini itu, dan senang mencari dan memecahkan masalah soal-soal.

\section{SIMPULAN DAN SARAN Simpulan}

a. Penerapan Model Pembelajaran Kooperatif Teknik Think Pair Share pada Mata Pelajaran Dasar-dasar Perbankan siswa kelas X Akuntansi SMK Muhammadiyah Magelang Tahun Ajaran 2016/2017 dilaksanakan melalui langkah penyampaian inti materi dan kompetensi yang ingin dicapai, siswa diberikan latihan soal untuk dipikirkan (Think) jawabannya secara individu, siswa berpasangan (Pair) untuk berdiskusi, siswa mempresentasikan (Share) hasil disikusi bersama pasangannya, guru mengarahkan pembicaraan pada pokok permasalahan dan menambahkan materi yang belum diungkapkan siswa, menyimpulkan materi, menutup pelajaran. Dengan Penerapan Model Pembelajaran Kooperatif Teknik Think Pair Share pada Mata Pelajaran Dasar-dasar Perbankan dapat diketahui bahwa siswa dapat menyelesaikan soal dasardasar perbankan yang diberikan guru, siswa mengerjakan soal perbankan dengan kemampuannya sendiri saat menemui kesulitan, siswa memperhatikan pada saat guru menyampaikan materi, siswa mengerjakan soal perbankan secara mandiri, siswa bersemangat saat pelajaran perbankan, siswa mempunyai alasan atas hasil pekerjaannya, siswa tidak terpengaruh dengan jawaban berbeda dari siswa lain pada saat presentasi, dan siswa segera mengerjakan soal perbankan yang diberikan guru.

b. Penerapan Model Pembelajaran Kooperatif Teknik Think Pair Share dapat meningkatkan Motivasi Belajar pada Mata Pelajaran Dasar-dasar Perbankan Siswa Kelas X Akuntansi SMK Muhammadiyah Magelang Tahun Ajaran 2016/2017 dibuktikan dengan tercapainya kriteria minimal yaitu sebesar $75 \%$ pada tiap indikator. Data hasil observasi memperoleh skor rerata Motivasi Belajar pada Mata Pelajaran Dasar-dasar Perbankan sebesar $81.13 \%$ dan data hasil angket skor rerata Motivasi Belajar pada Mata Pelajaran Dasar-dasar Perbankan sebesar $77.88 \%$.

\section{Saran}

\section{a. Bagi Guru}

Penelitian ini dapat dijadikan pertimbangan untuk diterapkan pada kegiatan belajar mengajar karena telah terbukti Model Pembelajaran Kooperatif Teknik Think Pair Share dapat meningkatkan Motivasi 
Belajar pada Mata Pelajaran Dasardasar Perbankan siswa kelas $\mathrm{X}$ Akuntansi SMK Muhammadiyah Magelang Tahun Ajaran 2016/2017. Oleh karenanya diharapkan guru memakai Model Pembelajaran Kooperatif Teknik Think Pair Share dalam kegiatan belajar mengajar supaya peserta didik memiliki motivasi yang lebih tinggi.

b. Bagi Peneliti Selanjutnya

Untuk peneliti berikutnya diharapkan untuk dapat memberikan kesempatan yang sama pada semua kelompok untuk mempresentasikan (share) hasil pekerjaan mereka.

\section{DAFTAR PUSTAKA}

Isjoni. (2013). Pembelajaran Kooperatif: Meningkatkan Kecerdasan Komunikasi Antar Peserta Didik. Yogyakarta: Pustaka Pelajar.

Mulyasa. (2013). Praktik Penelitian Tindakan Kelas. Bandung: Remaja Rosdakarya.

Sugiyono. (2010). Metode Penelitian Pendidikan. Bandung: Alfabeta.

Sardiman. (2012). Interaksi dan Motivasi Belajar Mengajar. Jakarta: Rajawali Pers. 